\title{
Hermeneutical Trajectories from the Third World: Aijaz Ahmad on Edward Said
}

\author{
Stuti Khare \\ India \\ stutikhare80@gmail.com \\ DOI: https://doi.org/10.24113/ijellh.v9i4.10984
}

\begin{abstract}
Aijaz Ahmad has made serious critical interventions in Marxist and Postcolonialist readings of literature and culture. His book, In Theory: Classes, Nations, Literatures (1992) has made significant contribution to the postcolonial critical debates. It is a collection of critical articles with deliberations on postcolonial theory from different perspectives. In this book, one article on Edward Said discusses Said's contribution to postcolonial discourse in the paradigm of Western influence on Eastern cultural narratives. Ahmad argues that Said's critical writings on orientalism suffer from inconsistencies, overgeneralizations and selective applications. These methodological aberrations, Ahmad asserts, have shaped the trajectories of Said's critical oeuvre. He criticizes Said for adopting western theoretical models for the cultural analysis and interpretations which are deeply immersed in the capitalist power structures. Ahmad accuses him of appropriating the western knowledge-structures for theorizing the Orient. His analysis of Said goes beyond the limits of critical debates as he questions Said's vocation and space. He, in effect, considers Said an inauthentic critical voice. According to Ahmad, Said's successful career in the West has rendered him incapable of a genuine engagement with the Orient. In this paper, I have attempted a critical re-reading of Ahmad's
\end{abstract}


arguments to suggest that Ahmad's criticism of Said is intentionally provocative, seeking attention without engaging with Said's theoretical perspectives in a comprehensive manner. Keywords: Orientalism, Post-Colonial Theory, Hermeneutics, Marxism, Discourse.

"To know inauthenticity is not the same as to be authentic"

Paul de Man, Blindness and Insight

Post-colonial criticism examines the signifying effects of the western texts on the colonized subjects. The postcolonialists argue that the colonial power exerts its negative influence on the cultural manifestations of the colonized subject. The creativity and the hermeneutical practices, both are appropriated by the colonial power in such a way that the signifying effects of the cultural narratives of the colonial power create a negative impact on the structures of creative imagination and the hermeneutic practices. Thus the unholy nexus between the western cultural textualities and the colonial power creates the colonized subjectivities, and their cultural representations.

The postcolonial critical practices are disposed to use methodologies that interpret and analyze the culture of the power in opposition to the culture of the powerless colonized subjects. The methodological necessities of such cultural criticism do create certain inconsistencies, exaggerations, ambivalences and generalizations. The spirit of such cultural criticism resides in the fact that the culture of the dominant class adversely affects the peripheral subjectivities. To bring forth the negative effects of cultural dominance of the colonizer, the native culture has to be poised with all positive energy against the negative influence of the colonizer's culture of power. These inconsistencies and ambivalences in the hermeneutics of postcolonial discourse are stretched too far by the critical mind whose primary objective is not to analyze and interpret, but to criticize and trivialize.

Aijaz Ahmad is a Marxist philosopher, literary theorist and political commentator. He is currently the Chancellor's Professor at the UC Irvine School of Humanities' Department of 
Comparative Literature. His book In Theory: Classes, Nations, Literatures is a collection of critical essays in which he primarily discusses the role of postcolonial theory and theorists in the movement against colonialism and imperialism. According to Benita Parry:

Ahmad's mission to effect a break with the existing theoretical formulation" in the discussion of imperialism, derives from his allegation that this is now in the hands of literary theorists who practice "a post modern anti-colonial derisive of Marxist discourse." While such a charge is not without cause, it relies on conflating related but distinct and internally diverse disciplines (Parry 121).

Ahmad's argument against the advocates of poststructuralist and postmodernist conceptions of material history is based on the fact that this brand of postcolonial inquiry is quite reductive and is devoid of any historical or political meaning. It completely disregards material reality, global power imbalances and unequal distribution of wealth and has become a mere jargon, "simply a polite way of saying not-white, not-Europe, or perhaps not-Europe but-inside-Europe" (Ahmad 8).

The book was an instant success in the academia and it caught the imagination of the best-known minds in the field of literary enquiry. In India, it became a celebrated text as it filled the gap of critical engagement with the West that has existed for a long time. The reception was almost euphoric as the academicians celebrated a critical mind from the hinterland of India who can take on the grand narratives of literary theory, especially from the dominant groups like the post-colonists, the deconstructionists and others. This kind of reception of Aijaz Ahmad by the academia is justified considering the almost negligible serious critical engagements in Indian academic environment.

There is a kind of fascination with Karl Marx in these post-capitalist times. Marx is a symbol of redemption from guilt, the guilt of not doing enough for the marginalized. 
Ahmad's Marxist approach to the study of Orientalism and other (post)colonial discourses is prominently reflected in his celebrated work, In Theory. His obsessions with the materiality of Marxism distort his critical methodologies to the extent that his interpretative oeuvre gets transformed into a narrative of personal likes and dislikes, devoid of critical rigour:

A book that promises a Marxist intervention in the cultural critique of imperialism will quicken great expectations among those who are discontented with the frequent incuriosity about the inscriptions of political economy in its representational systems. As one such readers of Aijaz Ahmad's In Theory, I anticipated an analysis attentive to the making and effects of imperialism's independent practices, and commensurate with the present state of the debate. ...I must, however, also register my distaste for the conduct of an argument which, in deploying recrimination as an analytic strategy, misrepresenting the substance of alternative inquiries, and adducing these to retrograde ideological interests, cannot but recall that device of polemical assassination contrived long ago by traditional Communist parties in an attempt to disable other left tendencies (Parry 121 ).

In this work, there are readings of self-exiled third world intellectuals, scholars and creative writers that include Frederic Jameson and Salman Rushdie. It contains a lengthy critique of Edward Said's Orientalism which, according to Ahmad, duplicates the very liberal humanist tradition that it seeks to undermine. The polemics in which Ahmad indulges from the very beginning of his analysis is symptomatic of his deep-rooted prejudices and superficial approach against Edward Said's literary criticism. Ahmad has expressed serious reservations about Said's work, especially on his intellectual credibility and his professional limitations: 
I disagree with him so fundamentally on issues both of theory and of history that our respective understanding of the world - the world as it is now is, and as it has been at many points over past two thousand years or so - are simply irreconcilable (159).

On scrutiny, after the celebration, even in the Indian context, we realize that Ahmad's In Theory, especially his criticism of Said's Orientalism, is exclusionary, authoritative and self-contradictory in nature rather than analytical and substantial. It seems more of a critic who is desperate to stage dramatic reversals and rushes to indulge in critical engagement leading to the unsubstantiated conclusions.

In this paper, I attempt to analyze Ahmad's reading of Said in his article "Orientalism and After" to demonstrate that Ahmad's readings of Said cannot be considered as sincere, honest and productive criticism.

Ahmad questions Said for a number of theoretical, ideological and methodological inconsistencies and ambivalences. He criticizes Said primarily on the following counts:

a) Ahmad considers Said's location and position untenable as a postcolonial critic as his academic position in the West renders him incapable of genuine experience of the Orient.

b) The essentialism of the West, Ahmad charges, has seeped into the cultural consciousness of Said and it gets reflected as Said maneuvers the theoretical positions of post-colonial criticism.

c) Said is also charged of ambivalences, generalizations and inappropriate illustrations and selective arguments in the process of establishing his critical acumen. He is criticized for using paradoxical arguments that annihilate each other, rendering his critical enterprise incapable of any substantial value.

e) Negative eclecticism: Ahmad accuses Said of creating simplistic, reductive categories that suit his convenience. 
In the following section, I would discuss the validity of Ahmad's critique of Said. My argument is that Ahmad's criticism of Said is not justifiable on several counts. In fact, it appears that by indulging in trivialization of Said, Ahmad intends to establish himself as a critical voice of substance, without making serious engagements with Said's ideas and writings.

a) Ahmad begins this article by discrediting the fundamental identity of Edward Said. His contention is that Said's Palestinian identity restrains him in achieving objectivity in Oriental discourse, leading to further restrictions of the range and width of critical enquiry. His whole attempt is to focus on Said's Palestinian identity and his opportunistic career in the West. By implication, Ahmad is trying to say that a subject (an individual) who is situated in the Western cultural space, materially benefitting from its resources, cannot authentically participate in critical engagements. He falls little short of calling Said a hypocrite who is "A Palestinian living and teaching in the USA, armed with not much more than a humanist intellectual training, a successful career as literary critic, and a splendid mastery over wide areas of European literary textuality (Ahmad 161). According to Ahmad, due to his training in classical mode of scholarship, Said is intellectually incapable of dealing with such complex issues. He questions Said's authenticity even as an "oriental subject" as his oriental identity is washed in the streams of Western culture and knowledge apparatuses. Hence, reversely, Ahmad is strongly critical of Said's self description as the 'Oriental subject' which he finds "somewhat one-sided and therefore somewhat hazardous for anyone whose own cultural apparatus is so overwhelmingly European and who commands such an authoritative presence in the American university" (Ahmad 173).

Such polemical assertions on the part of a critic are obviously attempts to discredit the rich dividends that the cultural critics of oriental identity are capable of. By implication, is Ahmad trying to assert that a critical mind need to be ensconced in the primitive settings of 
the culture to which the critic belongs, and only by fulfilling this condition true and genuine criticism is possible? Nothing can be more spurious than this argument of Ahmad on Said. Said's oriental identity is in no way a disqualification for engaging in the intellectual debates of Orientalism. It seems that such criticism is nothing but a deliberate attempt to question the serious intellectual contribution that Said has made to the debates on the third world identities. In fact, by this prescription, Ahmad's own critical writings need scrutiny of truthfulness. Ahmad's arguments against Said can be applied to his own critical methodology: Ahmad claims to be the authentic voice of Marxism on the basis of the marginal identity, (an intellectual from the third world). Yet he targets the intellectuals of the "Third World" origins who have emigrated to the West "for professional reasons but use words like 'exile' or 'diaspora' - words which have centuries of pain and dispossession inscribed in them - to designate what is, after all, only personal convenience." (Ahmad 85, italics mine). According to Ahmad, these intellectuals have established themselves as academicians and scholars in metropolitan countries and have created false and distorted conception of the "Third World".

b) Ahmad accuses Said of creating the essentialist discourse in his selection of Western canonized texts that are strategically used for creating the theory of Orientalism. He contends that Said's criticism of the West for essentializing the Orient is counterproductive as Said too has essentialized the West by his Orientalist discourse. According to Ahmad, Said, in his project of post-colonialism, has represented the West as a unified, trans-historical, organic unit, a continuously evolving tradition from the Antiquity to the present. Said has constructed the history of his western discourse on the basis of certain masterpieces, and thus privileged the canonical European literature. Ahmad contends that in his attempt to create a history of Orientalism, Said identifies the Enlightenment as a "unified trajectory and master-sign, of 
both Orientalism and colonialisn" (164) and thus he commits the sin of essentializing the west:

The particular texture of Orientalism, its emphasis on the canonical text, its privileging of literature and philology in the construction of 'Orientalist' knowledge and indeed the human sciences generally, its will to portray a West which has been the same from the dawn of history to the present and its will to traverse all the main languages of Europe - all this, and more, in Orientalism derives from the ambition to write a counter-history that could be posed against Auerbach's Mimesis, a magisterial account of the seamless genesis of European realism and rationalism from the Greek antiquity to the modernist movement (Ahmad 163).

c) According to Ahmad, Said's attempt to write a counter history of European rationalism is marked by ambivalence and paradoxes. This paradox is played on a larger and more complex level in Said's perspective on European High Humanism. On the one hand, he finds European Humanist literature an accomplice in "the inferiorization of the 'Orient"' (Ahmad 164), on the other he seems to be preoccupied with "the canonical author, with tradition, with sequential periodization" (168) and thus endorses the values of humanist liberalism like accommodation, tolerance, cultural pluralism and so on and so forth: “...humanism-asideality is invoked at the same time when humanism-as-history has been rejected so unequivocally" (Ahmad 164). Erich Auerbach, who is to be represented as the master of European hegemonic knowledge in Said's discourse, becomes an "absent anti-hero", "the emblem of scholarly rectitude, a lone figure defending humanist value in the midst of holocaust" (Ahmad163). Ahmad is highly critical of Said's tendency of alternating between inordinate praise and wholesale rejection: 
Said denounces with Foucauldian vitriol what he loves with Auerbachian passion so that the reader soon begins to detect a very personal kind of drama being enacted in Said's procedure of alternately debunking and praising to the skies and debunking the same book, as if he had been betrayed by the object of his passion (Ahmad164).

Thus, according to Ahmad, Said duplicates and subscribes to the same European High Humanism that he claims to contest. Furthermore, Ahmad asserts that by tracing Orientalist thought all the way back to Ancient Greece, it becomes unclear in Said's work whether Orientalism is a product of Colonialism, or whether Colonialism is, in fact, a product of Orientalism. He accuses Said of providing a continuous streaming history, with no break, no rupture and thus anti- Foucauldian in nature. Said talks about eighteenth century as the starting point of Orientalism, as a construct; but Ahmad asks, "If there really is only this seamless and incremental history of orientalist discourse from Aeschylus to Dante to Marx to Bernard Lewis, then in what sense would one take 18th century as the roughly defined starting point?" (Ahmad 181).

In this context, Rakesh Nambiar observes:

Ahmad first problematized the methodological approach in Orientalism by relying too much on Western epistemology and the very traditions which had the virtues of tolerance, universality, non-racialistic pluralism, liberalism, humanism, sympathetic participation in the emotional experience of the Other, etc. Ahmad conveniently forgets that rational doctrines, the bedrock of western epistemology was unavailable to the colonized and it was relatively absent as critical tool of assessment for the Oriental in his theory and praxis on the non-western world. Even within the equation between the Orient and 
Occident there was a relative superiority of the west in terms of its position and hegemony of ideas (Nambiar "Renegotiating")

Ahmad observes that Said's approach to Marxism is also marked by the same ambivalence. According to Ahmad, Said tries to bring together a number of irreconcilable theoretical and political positions like those of Julien Benda, "the rabid anti-communist" and Antonio Gramsci, "one of the more persevering communists of the century" (Ahmad 170). On the one hand, Benda "a man possessed by notions of High Aesthetics", has been praised by Said as "one of the exemplary intellectuals of this century" (Ahmad 169) and on the other, he has been equated with Antonio Gramsci, whose Marxist leanings are quite conspicuous. Ahmad views this as Said's way of "domesticating the revolutionary content of Gramsci's thought" (Ahmad 169).

This also appears to be a misreading of Said, Benda, Gramsci and others who understand the unholy alliance that the power-structures make with the intelligentsia and academia. The intellectuals on the side of power help in legitimizing the brute power in all its cruel acts. During Hitler's rule, the role of intelligentsia serves as a befitting example. Hence, this kind of polarization of the aestheticians and the intellectuals that Ahmad indulges in seems to be an intentional distortion of two separate intellectual spaces.

d) Indulging in polemical criticism, Ahmad also accuses Said of generalizations, the "homogenizing sweep" (Ahmad 197), which at times seems contradictory and ambiguous. Said proposes Orientalism as a kind of discourse, but at the same time he seems to follow the Auerbachean tradition of High Humanism which is highly "un-Foucauldian". Said's understanding of Derrida, Nietzsche and Foucault is perceived by Ahmad with condescension for being utterly simplistic and reductive. According to Ahmad, throughout Orientalism, Said fails to decide whether he considers Orientalism to be merely a product of a system of representations, in the post-structuralist sense attached to it by Derrida and Foucault, or a 
system of misrepresentation, wilfully produced by the West. In an essay entitled "The Voyage In: Third World Intellectuals end Metropolitan Culture”, Said recommends that nonWestern writers should be seriously taken by the western readers. But his main argument is premised on a rather strange distinction between two kinds of intellectuals - colonial or postcolonial. And, in this typology also, his selection of the representatives of both categories is arbitrary and reductive: he places the Trinidadian communist C.L.R. James and the Arab nationalist historian George Antonius into the category of colonial intellectuals and the Malaysian writer Alatus and the Indian author Ranjit Guha fall in the category of postcolonial intellectuals. According to Ahmad, the main reason for this selection is an unmistakable "autobiographical self-referentiality" (201) on part of Said, and his apparent fascination for "those intellectuals of non-Western origin who command a high degree of technical competence and have chosen, both in the colonial and post-colonial periods, to locate themselves in the West" (Ahmad 206).

Similarly, as Ahmad points out, Said strategically uses words like 'we' and 'us' in different contexts to refer to Palestinians, Third World intellectuals, academics in general, humanists, Arabs, Arab-Americans, and the American citizens at large. The phrase, 'the Oriental subject' is arbitrarily appropriated as 'the colonial subject', and later as 'the postcolonial subject'. By criticizing Said's use of such terms in his theoretical discourse, Ahmad deliberately ignores the functional aspects of language and rhetoric that is used in critical debates. In the narratives of identity, the pronouns like "I" and "we" are common features of language. In no way these terms can be considered inappropriate or unjustifiable as the context in which Said theorizes on the postcolonial subjectivities necessitates such usages. In fact, Ahmad exposes his own triviality by making such spurious arguments.

e) Ahmad accuses Said of theoretical eclecticism which "runs increasingly out of control" (Ahmad 200). According to Ahmad, Said borrows his language and his content from so many 
different kinds of disciplines and conceptual frameworks that one is "simply bewildered" (Ahmad182). Pointing to Said's "audacity of combination", Ahmad remarks:

Who, after all, had ever thought that Lamartine and Olivia Manning, Chateaubriand and Byron, Carlyle, Camus, Voltaire, Gertrude Bell, the anonymous composers of El Cid and the Chanson de Roland, Arabists like Gibb, colonial rulers such as Cromer and Balfour, sundry quasi-literary figures like Edward Lane, scholars of Sufism like Massington, Henry Kissinger - all belonged in the same archive and composed a deeply unified discursive formation (Ahmad 177).

Edward Said is a critic of intellectual rigour and his endeavour was to liberate the Orient from the misrepresentations of the West. To appreciate the work of a critic in true sense, one has to situate oneself in the theoretical framework that the critic creates. The theoretical framework is shaped by the context of the intellectual commitment that the critic pursues. The intellectual motives and pursuits of Said were motivated by the humanistic perspectives that guide the intellectual engagements of the highest order. The contradictions and ambiguities that Ahmad refers to in Said are part of the complex framework that sustains the very purpose of Said's critical endeavour. Ahmad's criticism of Said seems to be a deliberate attempt to diminish the depth of Said's achievements. It is an attempt that can best be understood as an attempt of a critic who misuses his mind to equalize by trivializing the achievements of a true and genuine intellectual. Ahmad's reductive approach to Said fails to explore the immense possibilities of enriching the Eastern narratives that Said's critical oeuvre offers. The issue of misrepresentation of the Orient, which is the primary concern of Orientalism is an intentional and convenient overlooking in which Ahmad deliberately indulges. Perhaps he wants to attract the attention of the academia by indulging in such intentional misreading of Said. To some extent, Ahmad has succeeded in this attempt. He 
calls Orientalism "a deeply flawed book". I think one cannot be more 'flawed' than Ahmad. I conclude with a quote from Benita Parry.

I am distressed, therefore, that Ahmad's collection of essays obliges me to write a review where an inventory of errors, reductive procedures, and rancor must take precedence over consideration of the perspectives it might otherwise have offered to the continuing theorization of imperialism. Ahmad's critique relies on 'conflating related but distinct and internally diverse disciplines: Colonial Discourse Analysis, Theories of Third World Literature, Subaltern Studies, researches into African-American culture, - even Salman Rushdie's fiction is included. Ahmad's procedure is to distort the theoretical paradigms of these various inquiries, and then to impugn the intellectual authority of protagonists by attributing the provenance of their thinking to comprador class origins and subsequent "embourgeoisement" within the elite academic institutions of the metropolis (Parry 121). 


\section{Works Cited}

Ahmad, Aijaz. "Orientalism and After: Ambivalence and Metropolitan Location the Work of Edward Said." In Theory: Classes, Nations, Literature. Oxford: Oxford University Press, 1992. 159-220. Print.

Nambiar, Rakesh. "Re-Negotiating Orientalism through the prism of Edward Said vs. Aijaz Ahmd debate on Marx, Europe and East.” Avartan. (2013):1-5. Web. 7 Feb. 2021.

Parry, Benita. “A Critique Mishandled” Social Text. Durham, North Carolina: Duke University Press. 35. (1993): 121-133. Web. 25 Dec. 2020.

---. Edward Said and Third-World Marxism. College Literature: A Journal of Critical Literary Studies. West Chester: John Hopkins University Press. 40.4. (2013):105-126. Web. 7 Feb.2021.

Said, Edward. Orientalism: Western Conceptions of the Orient, New Delhi: Penguin Books India, 2001. Print

--- . "The Voyage In: Third World Intellectuals and Metropolitan Cultures”. Arab Nation, Arab Nationalism. Ed. Derek Hopwood. London: Palgrave Macmillan, 2000. 79101. Print. 